\title{
NAFTA: \\ Promises And Deliveries
}

Macgorine Cassell, Fairmont State University

Donatus I. Amaram, Virginia State University

Rebecca Blake, Candidate for MBA Program

\begin{abstract}
This paper specifically addresses NAFTA's effectiveness in fulfilling one promise from its preamble: "create new employment opportunities and improve working conditions and living standards in their respective territories." Research concludes that any improvements/deterioration concerning job creation, working conditions or living standards could be attributed to myriad factors, NAFTA being only one.
\end{abstract}

\section{INTRODUCTION}

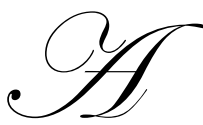

$\mathrm{t}$ a recent Democratic debate broadcasted on $\mathrm{CNN}$, candidates were asked if elected what would be their top priority during their first 100 days in office. Of the eight contenders, only one addressed trade relations. Presidential hopeful Dennis Kucinich responded, "what I intend to do is to be a president who helps to reshape the world for peace...making sure that we cause the nations of the world to come together for fair trade, cancel NAFTA, cancel the WTO, go back to bilateral trade conditioned on workers' rights and human rights" (2007). Government officials, promoters and critics alike have all expressed their views on the North American Free Trade Agreement (NAFTA) since its controversial beginning on December 17, 1992 when NAFTA was signed by President Bush (senior), Mexican President Salinas and Canadian Prime Minister Mulroney. On November 17, 1993, the law was approved by a vote of 234 to 200 in the House and 60 to 38 in the Senate. President Clinton signed the bill into law on December 8, 1993 and it took effect January 1, 1994.

The primary purpose of NAFTA was to increase trade and foreign investment through a reduction in tariffs and other barriers to business between the three countries. Through creation and implementation of NAFTA the United States, Canada and Mexico governments promised to do the following in the preamble of the agreement:

- $\quad$ STRENGTHEN the special bonds of friendship and cooperation among their nations;

- $\quad$ CONTRIBUTE to the harmonious development and expansion of world trade and provide a catalyst to broader international cooperation;

- $\quad$ CREATE an expanded and secure market for the goods and services produced in their territories;

- $\quad$ REDUCE distortions to trade;

- $\quad$ ESTABLISH clear and mutually advantageous rules governing their trade;

- $\quad$ ENSURE a predictable commercial framework for business planning and investment;

- $\quad$ BUILD on their respective rights and obligations under the General Agreement on Tariffs and Trade and other multilateral and bilateral instruments of cooperation;

- $\quad$ ENHANCE the competitiveness of their firms in global markets;

- $\quad$ FOSTER creativity and innovation, and promote trade in goods and services that are the subject of intellectual property rights;

- $\quad$ CREATE new employment opportunities and improve working conditions and living standards in their respective territories;

- UNDERTAKE each of the preceding in a manner consistent with environmental protection and conservation;

- $\quad$ PRESERVE their flexibility to safeguard the public welfare;

- $\quad$ PROMOTE sustainable development; 
- $\quad$ STRENGTHEN the development and enforcement of environmental laws and regulations; and

- $\quad$ PROTECT, enhance and enforce basic workers' rights;

(Foreign Affairs and International Trade Canada, 2006).

The purpose of this paper is to assess the effectiveness of the North American Free Trade Agreement with respect to fulfilling one promise from its preamble: "create new employment opportunities and improve working conditions and living standards in their respective territories." Reviewing the success/failure of NAFTA is important for at least two reasons (1) to determine if NAFTA has been successful in fulfilling its promises, and (2) to learn from the past and determine necessary changes prior to adoption of future agreements or if such agreements are even beneficial/necessary. Published literature was reviewed to gather data and analyze each aspect of the promise individually:

- $\quad$ Create new employment opportunities

- Improve working conditions

- Improve living standards

\section{CREATE NEW EMPLOYMENT OPPORTUNITIES}

An article published in Newsweek, "NAFTA's Scorecard: So Far So Good," stated the following about the United States, "since the treaty went into effect in 1994, the U.S. Labor Dept. has certified about 316,000 jobs as threatened or lost due to trade with Mexico and Canada. That number--which economists such as Hufbauer see as a good measure of the job impact of this trade--is quite small, since the U.S. economy has added about 20 million jobs over that time period" (2001). Economists may agree with this statement, but what about those 316,000 workers who had to go job-hunting as a result of an agreement that promised job creation?

\section{Canada}

Foreign Affairs and International Trade Canada stated, "the enhanced economic activity and production in the region have contributed to the creation of more and better paying jobs for Canadians. Close to 3.1 million net new jobs have been created in Canada since 1994, representing an increase of $126.6 \%$ over pre-NAFTA employment levels" (2006). Jean-Yves LeFort's article entitled "Free Trade's Big Lie: NAFTA Has Failed to Create Quality Jobs or Close the Income Gap" addressed job creation in Canada. The article reported "NAFTA defenders point to the creation of "millions" of new jobs since the agreement was implemented, but a 2004 study by the Canadian Centre for Policy Alternatives (CCPA) questions the quality and stability of those jobs. According to the CCPA, 560,000 jobs were created in 2002, but 40 per cent were part-time and 17 per cent represented selfemployed persons" (LeFort, 2007).

\section{Mexico}

Research shows that Mexico did experience job creation during the early years of NAFTA, but many say jobs created were not spread out geographically or "good" jobs. Many plants were built along the US-Mexico border called Maquiladoras. These assembly plants receive imported parts and assemble them for export. "Maquiladora employment grew rapidly over the last two-and-a-half decades, from 60,000 jobs in 1975 to 420,000 in 1990 to 1.3 million in 2000. Maquiladora factories remained largely unaffected by the recession of the mid 90s, given their limited dependence on the Mexican economy. Though these factories have thrived under NAFTA, they have contributed little to Mexico's development and internal markets" (Scott, Salas, Campbell, 2001). However, "more than 850 factories have shut down since 2000 -- some due to decreased demand for their products in the U.S., others because companies have relocated production to cheaper spots, especially China. Maquila employment is down more than 20\% from its October, 2000, peak of 1.3 million workers. (Smith and Lindblad, 2003).

\section{United States}

During the formative stage of NAFTA, many corporations made promises of new job creation if NAFTA was implemented. The article NAFTA's Broken Promises, published in The Multinational Monitor, in one study, "identified 83 specific promises by individual companies to increase jobs or exports if NAFTA was approved. Of 
the 83, seven companies kept those promises; 60 corporations broke their promises; and 16 were unwilling or unable to provide current data." For example, "in 1993 a General Electric representative told the House of Representatives Foreign Affairs Committee that sales to Mexico could support 10,000 jobs for General Electric and its suppliers. We fervently believe that these jobs depend on the success of this agreement." Today, a GE spokesperson is unable to cite a single job created due to trade with Mexico -- and the NAFTA TAA has certified that GE has laid off 2,318 workers due to NAFTA" (1997).

In a 2001 Newsweek article titled "NAFTA's Scorecard: So Far So Good" the author indicated, "while some U.S. workers have lost their jobs because of it, the number has been far fewer than opponents predicted. And the best available studies show that on balance NAFTA has boosted jobs and cut inflation without hurting wages" (2001). This view is not shared by all experts. One economist, Robert Scott concluded, "growing trade deficits with Mexico and Canada have displaced production that supported roughly 660,000 (manufacturing only) and 1.0 million (total) U.S. jobs since the agreement took effect in 1994. Export growth since 1994 supported an additional 1 million U.S. jobs, while imports displaced domestic production that would support 2 million jobs" (Robert, 2006). To be even more specific Scott went on to say, "growing trade deficits with Mexico and Canada have displaced production that supported 1,015,291 U.S. jobs since NAFTA took effect in 1994...The 1 million job opportunities lost nationwide are distributed among all 50 states and the District of Columbia, with the biggest losers, in numeric terms: California (-123,995), Texas (-72,257), Michigan (-63,148), New York $(-51,582)$, Ohio (-49,886), Illinois (47,701), Pennsylvania $(-44,173)$, Florida $(-39,987)$, Indiana $(-35,157)$, North Carolina $(-34,150)$, and Georgia $(-$ 30,464)" (Robert, 2006). Another viewpoint concerning this matter was published in a Newsweek article entitled "Free Trade Deserves a Fast Track." The article noted, "NAFTA has also helped the U.S. economy in a more subtle way that hasn't been as widely appreciated. With or without NAFTA, low-skilled jobs would have left the U.S. NAFTA helped direct many of those jobs to Mexico instead of, say, China. By keeping those jobs close to home, NAFTA encouraged production sharing--the swapping of parts back and forth across the border in ways that take advantage of each country's strengths. Plastic molding operations in El Paso, for example, make parts that are shipped to Mexico for others to assemble. If those assembly jobs had gone to China, it's likely that the molding jobs would have gone with them--rather than remaining in the U.S" (2001).

Groups of three or more adversely affected by NAFTA can file a petition for conditional assistance. As stated by the Department of Labor (DOL), "the Trade Act of 1974 established the TAA program to assist workers employed by a firm who lose their jobs or whose hours of work and wages are reduced as a result of increased imports or shifts in production to foreign countries... Workers certified as eligible to apply for TAA may receive reemployment services, training in new occupational skills, a job search allowance when suitable employment is not available in the workers' normal commuting area, a relocation allowance when the worker obtains permanent employment outside the commuting area, and Trade Readjustment Allowances (TRA) while the worker is in training" (2007). The following diagram published by the Department of Labor shows the number of petitions filed and those that were awarded certifications for years 1998-2006 


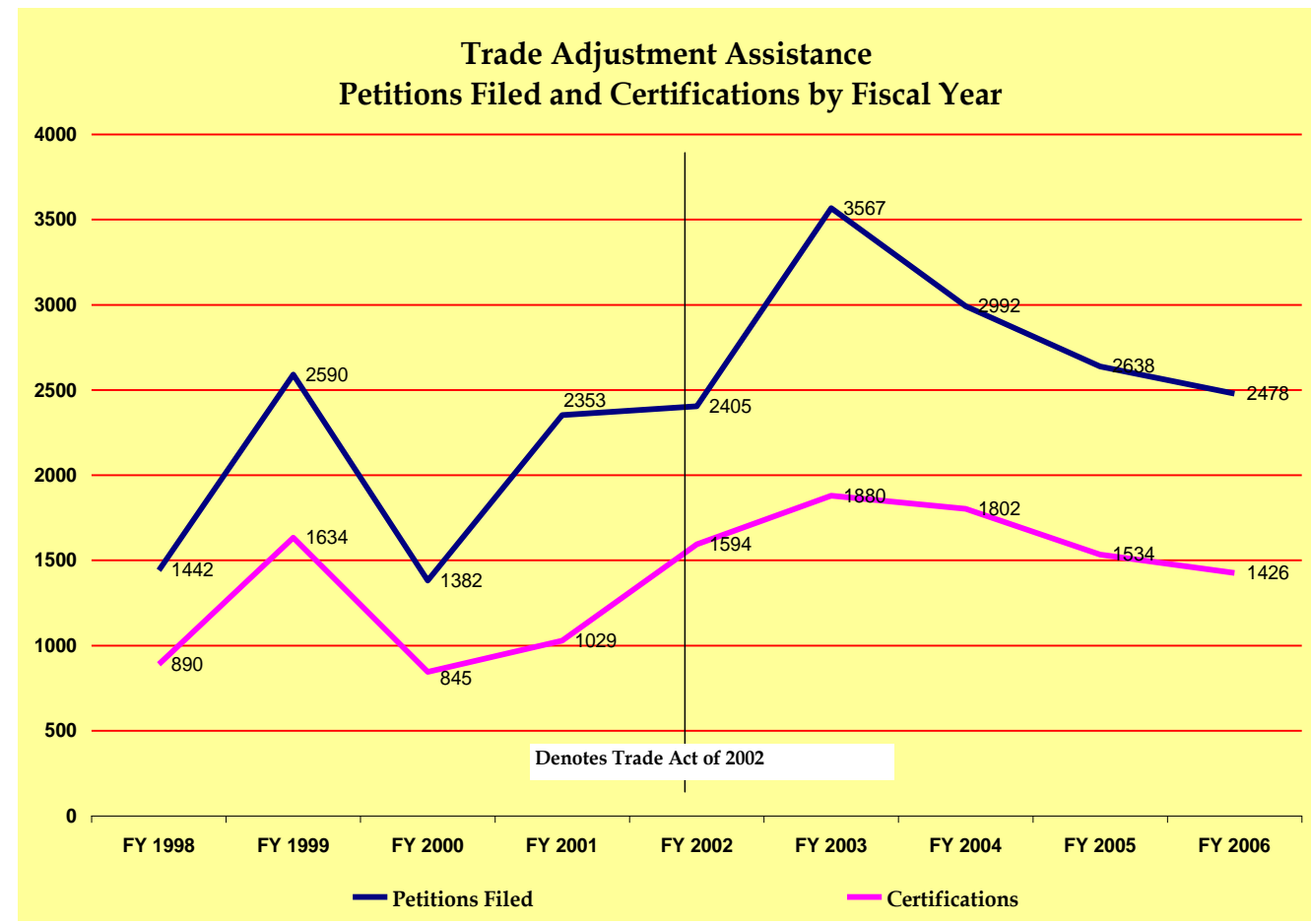

Research revealed a belief that the numbers are under-represented due to displaced workers lack of knowledge concerning the program. However, 4116 petitions have been awarded certifications during the years 1994-2003. The Department of Labor estimates that the certifications represent 525,407 people (DOL, 2006).

\section{IMPROVE WORKING CONDITIONS}

The coordinator of the Maquiladora Health and Safety Support Network, Garrett Brown, stated the 11 principles from the North American Agreement on Labor Cooperation (NAALC), a supplement from NAFTA, in his article "NAFTA's 10 Year Failure to Protect Mexican Workers' Health and Safety."

Freedom of association and the protection of the right to organize.

- The right to bargain collectively.

- The right to strike.

- Prohibition of forced labor.

_ Labor protections for children and young persons.

_ Minimum employment standards, including minimum wages and overtime pay.

_ Elimination of employment discrimination on such grounds as race, religion, age, sex or other grounds.

_ Equal pay for men and women.

_ Prevention of occupational injuries and illnesses.

_ Compensation in cases of occupational injuries and illnesses.

_ Protection of migrant workers.

\section{Canada}

The Canadian Immigration Consultant states that Canada "is a highly developed country with excellent working conditions" (2004). According to the website www.canadianalternative.com, "Canada boasts excellent working conditions and workers have many rights enshrined in law including minimum wage, pay equity, statutory holidays, paid vacation time, and parental leave benefits." An advocate for women's equality, Lois Moorcroft, 
("Minister of Justice, Education and the Women's Directorate in the Yukon's NDP government from 1996 to 2000") article from the Canadian Dimensions states, "according to the Canadian Charter of Rights and Freedoms: "Every individual is equal before and under the law and has the right to the equal protection and equal benefit of the law without discrimination and, in particular, without discrimination based on race, national or ethnic origin, colour, religion, sex, age or mental or physical disability. However, more than 25 years after the adoption of the Charter, the obligation to implement pay equity is still unmet. Although women now have the legal right to participate in the workforce and benefit economically from their labour without discrimination on the basis of sex, regardless of age, occupation or education, full-time working women still earn only 72.5 per cent of men's salaries" (Moorcroft, 2005). The Canadian Charter of Rights and Freedoms protects individuals from being victims of forced labor. In addition, Canada protects their youth by specifying appropriate age (usually 14) as well as when children can work to avoid interference with academic studies. Standards vary by province, but all companies employing youth must ensure safe working conditions.

\section{Mexico}

Working conditions in Mexico have been researched extensively. The Maquiladoras plants near the border are often reported as having hazardous conditions with minimal job security. "Wages, benefits, and workers' rights are deliberately suppressed in maquiladoras" (Scott, Salas, Campbell, 2001). As reported by the Coalition for Justice in the Maquiladoras, "women maquiladora workers in particular are vulnerable to sexual harassment by supervisors, termination due to pregnancy, and other gender-based discrimination" (2007). Many researchers share the belief that overall, "in Mexico, real wages have fallen sharply and there has been a steep decline in the number of people holding regular jobs in paid positions. Many workers have been shifted into subsistence-level work in the "informal sector," frequently unpaid work in family retail trade or restaurant businesses" (Scott, 2003). Concerning child labor, the U.S. Department of Labor reported, "there are an estimated 8 to 11 million children under the age of 15 working in Mexico. A relatively small number of children under the age of 14 are reportedly employed in the export-oriented maquiladoras, or assembly factories, in the border region between Mexico and the United States." The DOL also stated,

The Mexican Government recognizes the need to address the problem of child labor and has taken steps in that direction. In 1993, the International Labor Organization worked with the Mexican Government's Social Development Secretariat to develop a national action program for the eradication of child labor, with the financial assistance of UNICEF. The preliminary project resulting from this collaboration has not yet been approved. Other initiatives have been taken by the government to address the needs of children working in the informal sector. These are concerned with informing children and their parents of the rewards of education and providing them with various educational opportunities. The effect of these programs can not yet be determined.

Another issue presented during research is companies threatening to relocate to areas with cheaper labor. A Business Week article entitled "Mexico: Was NAFTA Worth It? A Tale of What Free Trade Can and Cannot Do" stated that "even with a rebounding economy, Mexico will not generate enough jobs to accommodate its fastgrowing workforce. While U.S. companies praise the work of their Mexican employees, they now make it abundantly clear that there are other, cheaper locales. The numbers tell the tale. An assembly line worker in Mexico earns $\$ 1.47$ an hour; his counterpart in China makes 59 cents an hour, according to a recent McKinsey \& Co. report. Top Delphi executives have warned for months that some production may be shifted to China because of the many cost advantages it offers over Mexico. Delphi and other automotive suppliers are courted every day by other countries, not only with lower-cost labor but also with new incentives and tax breaks," says David B. Wohleen, president for electrical, electronics, safety \& interior. "Mexico will need to significantly pick up the pace to remain a competitive alternative," he warns" (Smith and Lindblad, 2003).

\section{United States}

Employees in the United States have enjoyed favorable working conditions and been protected from various forms of discrimination prior to NAFTA. The Civil Rights Act of 1964 protects employees from being discriminated against based on race, color, religion, sex or national origin. The Fair Labor Standards Act enforces 
child labor laws restricts the number of hours that children under 16 can work and specifies occupations that are too hazardous for children. Forced labor is illegal in the U.S. and a national minimum wage has been in place prior to and throughout NAFTA. Although research has shown that women still earn less in the U.S., the Equal Pay Act of 1963 forbid pay discrimination based on sex. In the event of workplace injuries, employees are compensated during their recovery. The National Workers' Compensation website reports that, " $98 \%$ of employees in the US - over 192 million - are covered under the workers' compensation system."

One of the best indicators of working conditions is job related accidents/fatalities. The following table contains figures for Canada and the United States respectively of the number of on-the-job accidents that resulted in fatality for the first 12 years of NAFTA. The totals for Canada were obtained from Association of Workers' Compensations Boards of Canada and United States figures are from the United States Department of Labor.

\begin{tabular}{|c|c|c|c|c|c|c|c|c|c|c|c|}
\hline 1994 & 1995 & 1996 & 1997 & 1998 & 1999 & 2000 & 2001 & 2002 & 2003 & 2004 & 2005 \\
\hline 725 & 748 & 703 & 833 & 798 & 835 & 882 & 919 & 934 & 963 & 928 & 1097 \\
\hline 6632 & 6275 & 6202 & 6238 & 6055 & 6054 & 5920 & 5915 & 5534 & 5575 & 5764 & 5734 \\
\hline
\end{tabular}

Exact number of fatalities in Mexico are unknown, however, Brown's article, "NAFTA's 10 Year Failure to Protect Mexican Workers' Health and Safety," concluded the following after reviewing submissions to NAALC from Mexico, "the 10-year experience of NAALC submissions indicates a failure of this agreement to protect, let alone enhance, workers' health and safety on the job. The NAALC procedures themselves did not result in the correction of any health and safety hazards in workplaces where the worker submissions arose, and the NAALC ministerial agreements did not produce any discernable improvements in the effectiveness of government regulatory enforcement in Mexico" (Brown, 2004).

\section{IMPROVE LIVING STANDARDS}

\section{Per Capita Income}

Geoff Riley, Head of Economics at Eton College, explains in the article "Economic Growth" that higher living standards are "measured by an increase in real national income per head of population" (Riley, 2006). The Organization for Economic Co-Operation and Development (OECD) publishes national per capita income (U.S. dollars) annually. Per capita income figures obtained from the OECD for Canada, Mexico and United States respectively for 1994-2005 are below:

\begin{tabular}{|c|c|c|c|c|c|c|c|c|c|c|c|}
\hline 1994 & 1995 & 1996 & 1997 & 1998 & 1999 & 2000 & 2001 & 2002 & 2003 & 2004 & 2005 \\
\hline 21137 & 21968 & 22544 & 23713 & 24704 & 26217 & 27708 & 28506 & 29154 & 30083 & 31751 & 33495 \\
\hline 7114 & 6638 & 6992 & 7525 & 7835 & 8174 & 8874 & 8984 & 9210 & 9414 & 9989 &.. \\
\hline 26195 & 27296 & 28562 & 30090 & 31615 & 33243 & 35162 & 35775 & 36319 & 37498 & 39590 & 41657 \\
\hline
\end{tabular}

According to their statistics, with the exception of Mexico during the year 1995, all three countries had gradual increases annually during NAFTA's first 11 years. Mexico has not experienced the rapid growth predicted by experts. As reported in the Financial Times Business Limited Mexico's, "growth during that first decade was a bleak $1.8 \%$ on a real per capita basis...far worse than earlier in the century (in the quarter century from 1948 to 1973, Mexico grew at an average annual rate per capita of 3.2\%). President Vicente Fox promised 7\% growth when he took office in $2000 \ldots$ growth during his term of office averaged only $1.6 \%$ a year - and real growth per capita has been negligible" (Analy, 2007). Despite the growth, "according to World Bank estimates, over 45 percent of National population was living in moderate poverty in 2005. For extreme poverty, the total was 18 percent" (2007). 
Riley stated in a recent article, "rising national income boosts living standards and an expanding economy provides the impetus for a rising level of employment and a falling rate of unemployment" (Riley, 2006). It is therefore imperative to also consider the unemployment rates of the respective countries for the same period. The following table contains the unemployment rates for 1994-2005 for Canada, Mexico and the United States respectively.

\begin{tabular}{|c|c|c|c|c|c|c|c|c|c|c|c|}
\hline 1994 & 1995 & 1996 & 1997 & 1998 & 1999 & 2000 & 2001 & 2002 & 2003 & 2004 & 2005 \\
\hline 10.4 & 9.5 & 9.6 & 9.1 & 8.3 & 7.6 & 6.8 & 7.2 & 7.6 & 7.6 & 7.2 & 6.8 \\
\hline 3.5 & 5.8 & 4.3 & 3.4 & 2.9 & 2.1 & 2.2 & 2.1 & 2.4 & 2.5 & 3.0 & 3.5 \\
\hline 6.1 & 5.6 & 5.4 & 4.9 & 4.5 & 4.2 & 4.0 & 4.8 & 5.8 & 6.0 & 5.5 & 5.1 \\
\hline
\end{tabular}

Overall, Canada experienced a 3.6\% reduction in unemployment while Mexico ended the period with the same percentage that it began and the United States unemployment rate dropped $1 \%$.

Wages

Figures obtained from the U.S. Department of Labor reveal inequality in terms of wage increases for workers in the same industry among member nations. To illustrate, compare compensation increases (in U.S. dollars) for production workers in manufacturing for a ten-year span that NAFTA has been implemented (19952005). The table below contains figures obtained from the Department of Labor (2006) for the decade in question:

\begin{tabular}{|c|c|c|c|}
\hline Year & Canada & Mexico & United States \\
\hline 1995 & 16.50 & 1.70 & 17.17 \\
\hline 2000 & 16.48 & 2.07 & 19.65 \\
\hline 2005 & 23.82 & 2.63 & 23.65 \\
\hline
\end{tabular}

The overall increases are $\$ 6.48, \$ 7.32$ and .95 respectively.

\section{Other Determinants}

Determining air quality is an important first step to protecting the environment as well as the health of humans. In 2006, with support from the Commission for Environmental Cooperation (CEC), Mexico conducted its first national atmospheric air emissions inventory. According to World Bank, Mexico has seen improvements in some areas. In 1990, $82 \%$ of the population had access to an improved water source and the number jumped to $97 \%$ by 2004. Access to improved sanitation jumped from 58\% in 1990 to $79 \%$ in 2004 (2002). More improvements are necessary to match that of the United States and Canada both of which reported $100 \%$ for both water and sanitation for 1990 and 2004.

\section{CONFLICTING RESEARCH}

Research presented several challenges. For example, three years after NAFTA's implementation using the same statistics, the Brookings Institution and the Economic Policy Institute (EPI) report conflicting results of the effects of NAFTA. "Nora Claudia Lustig, a senior fellow in Brookings' Foreign Policy studies program and author of NAFTA: Setting the Record Straight," notes, "there is evidence that NAFTA has created more jobs than it destroyed." Jesse Rothstein and Robert E. Scott, authors of EPI's NAFTA and the States, conclude, "an exploding deficit in net exports with Mexico and Canada has eliminated 394,835 U.S. jobs since NAFTA took effect in 1994" (Ensign, 1994). NAFTA: two sides of the coin. These reports are not isolated; another article entitled "How NAFTA Failed Mexico" explained how different viewpoints could distort findings. "Americans' understanding of 
NAFTA's impact on the Mexican people is obscured in part by the gap between what Mexican elites tell U.S. elites and what Mexicans tell one another. Last December former Mexican President Carlos Salinas, who negotiated NAFTA, told a Washington conference of applauding corporate lobbyists, government officials and free-market think tankers that NAFTA was a great success. The next day, in Mexico City, a large group of very ardent Mexican farmers broke down the door of the lower house of the Mexican Congress to denounce NAFTA and demand that it be renegotiated. Similar demonstrations -- joined by teachers, utility workers and others -- have erupted throughout the country, closing bridges and highways and taking over government offices. Polls show that most Mexicans think NAFTA was bad for Mexico. Largely because of the agreement, Salinas is the most unpopular ex-president in modern Mexican history" (Faux, 2003). An article published in Newsweek entitled "Mexico: Was NAFTA Worth It? A Tale of What Free Trade Can and Cannot Do" compared approval ratings held by Mexicans which failed to indicate the success Salinas exclaimed. The article stated, "in an October survey by a leading pollster, only $45 \%$ of Mexicans said NAFTA had benefited their economy. That's down from the $68 \%$ who in November, 1993, saw the pact as a strong plus" (Smith and Lindblad, 2003). Research also differs on the affect of NAFTA on small businesses. Brown referred to dozens of research reports concerning NAFTA saying, "while the reports are unanimous in describing transnational corporations (TNCs) as the "winners" of NAFTA, almost all of them also identify the "losers" of the agreement to be the workers, family farmers and small businesses in all three countries, and the social and ecological environment on the U.S.-Mexico border" (Brown, 2004). In contrast, Foreign Affairs and International Trade Canada states,

NAFTA works for small and medium-sized businesses...Trade involves companies large and small creating jobs in our communities. Small and medium-sized companies are the engines of economic opportunity and job growth. They are the most vibrant ingredient of our economies. Their size makes them nimble, their products make them competitive and their energy makes them successful. Recent studies show that 97 percent of Canadian, 96 percent of U.S. and 95 percent of Mexican exporters are small and mediumsized businesses. When you consider that most new jobs are created by smaller businesses, it is clear that we need to encourage our small and medium-sized enterprises to look abroad for new opportunities - and reap the benefits of being part of North America's dynamic exporting sector (2003).

\section{CONCLUSIONS}

There is a plethora of published research concerning NAFTA; however, it is insufficient in terms of determining the success of the trilateral trade agreement on all fronts. Determining job creation as a direct result of NAFTA is more complicated then determining the success of NAFTA on aspects that can be proved numerically, for example increases in trade. Simply looking at statistics for annual job creation gives false assessment because many new jobs, if not most, cannot be linked to NAFTA. The research concludes that while there is a division of opinions on job creation the TAA petitions provide undisputable proof that jobs were lost as a result of NAFTA. The second criteria under study, working conditions, failed to reveal any significant NAFTA initiated changes/improvements. Lastly, when analyzing living standards the most significant finding was that all three countries experienced a gradual increase in per capita income. In conclusion, any improvements/deterioration of job creation, working conditions or living standards can be attributed to myriad factors, NAFTA being only one.

\section{REFERENCES}

1. About Canada. (2004). Canadian Immigration Consultants; http://www.canreach.com/.

2. Analy, J. (2007). Top Economist - Best Laid Plans - The North American Free Trade Agreement (NAFTA) Was Intended, Among Other Things, To Improve Mexico's Economy (and Thus Reduce Illegal Immigration). In Fact, It Worked To the Detriment of Mexico. Financial Times Business Limited.

3. Association of Workers' Compensation Boards of Canada. Canosh; http://awcbc.org/english/NWISP_Stats.asp.

4. Brown, Garrett D. (December 2004). NAFTA's 10 Year Failure to Protect Mexican Workers Health and Safety. Maquiladora Health and Safety Support Network; http://mhssn.igc.org/NAFTA_2004.pdf.

5. Census of Fatal Occupational Injuries. U.S. Department of Labor; http://data.bls.gov.

6. Ensign, David. (1997). NAFTA: Two Sides of the Coin. Spectrum: the Journal of State Government. 
7. Free Trade Deserve a Fast Track. (In Retrospect: The Benefits of NAFTA). (2001). Business Week, Issue 3740, 124.

8. Getting Work in Canada. www.canadianalternative.com.

9. Faux, J. (2003). How NAFTA Failed Mexico. The American Prospect.

10. Health Environmental Prevention. (2002) The World Bank Group, http://devdata.worldbank.org/hnpstats/thematicRpt.asp.

11. LeFort, Jean-Yves. (2007). Free Trade's Big Lie: NAFTA Has Failed to Create Quality Jobs or Close the Income Gap. Canadian Perspectives; www.canadians.org.

12. NAFTA's Broken Promises. (1997). Multinational Monitor, Volume 18 Number 5.

13. NAFTA's Scorecard: So Far So Good. (2001). Newsweek, 54.

14. NAFTA Works Brochure. (12/29/03). Foreign Affairs and International Trade Canada; http://www.international.gc.ca/nafta-alena/broch-main-en.asp.

15. North American Free Trade Agreement - Transitional Adjustment Assistance Estimated Number of Workers Covered by Certifications. (March 2006). Department of Labor; http://www.doleta.gov/tradeact/nafta certs.cfm.

16. Overview of the NAFTA. (December 2006). Foreign Affairs and International Trade Canada; http://www.international.gc.ca/nafta-alena/over-en.asp.

17. Riley, G., Economic Growth. (September 2006). AS Macroeconomics / International Economy' http://www.tutor2u.net/economics/revision-notes/as-macro-economic-growth.html.

18. Scott, Robert. (2006). NAFTA'S Legacy Rising Trade Deficits Lead to Significant Job Displacement and Declining Job Quality for the United States. EPI Briefing Paper \#173, 3-32.

19. Scott, R., Salas, Carlos, Campbell, B. (2001). New Reports Shows NAFTA Has Harmed Workers in All Three Countries. Economic Policy Institute.

20. Smith, G. and Lindblad, C. (2003). Mexico: Was NAFTA Worth It? A Tale of What Free Trade Can and Cannot Do. Business Week, p34.

21. Moorcroft, Louis. (4/15/2005). Newfoundland Women Want Pay Equity Too. Canadian Dimensions; http://www.vivelecanada.ca/article.php/20050415103547880.

22. Text of the Agreement. (June 2006). Foreign Affairs and International Trade Canada; http://www.dfaitmaeci.gc.ca/nafta-alena/agree-en.asp.

23. Journalists Resource Center for Workers' Compensation. The National Workers' Compensation Website; http://journalists.workerscompensation.com/general_information.php.

\section{AUTHOR PROFILES}

Dr. Macgorine A. Cassell earned his Ph.D. degree from United States International University. He is a Professor of Business Administration at Fairmont State University, West Virginia. His research and publications are in the areas of diversity in the workplace, intercultural communication, workplace violence, outsourcing, leadership practices and effectiveness.

Dr. Donatus I. Amaram earned his Ph.D. degree from Ohio State University. He is a professor of management at Virginia State University. His research and publications include topics in the areas of recruitment and retention; wage and salary administration; job satisfaction and workplace behavior; workplace violence, and drug testing in the workplace.

Rebecca Blake Bachelor of Science in Business from Fairmont State University and candidate for MBA program. 
NOTES 